\title{
Toxicity of Some Insecticides on the Hymenopteran Parasitoid, Bracon Hebetor (Hymenoptera: Braconidae)
}

\author{
By Ebeid, A.R. ${ }^{1}$, Huda H. Elbehery ${ }^{1}$, Farag, N.A. ${ }^{1}$, Gesraha, M.A. ${ }^{1}$
}

\begin{abstract}
The present study showed the acute toxicity and the effects of two widely used insecticides Profenofos, Cyfluthrin and the IGR (Runner) on the activity of the larval parasitoid, Bracon hebetor (Hymenoptera: Braconidae), a natural enemy of many insect pests. The direct application of the tested insecticides induced drastic effect on the adult male and/or female parasitoid, leading to $100 \%$ mortality within 24-48 hours post treatment for Cyfluthrin, 7 days post treatment for Runner treatment and 6 days post treatment for Profenofos. The indirect effect bioassays were conducted by applying five concentrations of each insecticide to the artificial diet of the host larvae (Galleria mellonella). The least toxic one to B. hebetor was Profenofos followed by Runner. While Cyfluthrin was the most toxic one which was dangerous on all life stages of $B$. hebetor, influencing the number of laid eggs by the parasitoid, percent of pupation and leading to failure of adult emergence.
\end{abstract}

Keywords: Bracon hebetor, Profenofos, Cyfluthrin, Runner

\section{Introduction}

The application of the chemical pesticides for pest control is known for being fast, efficient, simple to use and effective against the insect (Endo and Tsurumachi, 2001). Also, chemical pesticides might be on reason of the outbreaks of the pest due to their excessive and haphazard application. In addition, extreme application of chemical pesticides may leads to the mortality of various natural enemies more than the target pests (Way and Heong, 1994; Tanaka et al., 2000).

Family Braconidae is one of the most important families that parasitized either externally or internally on the larval stage of many important insect pests such as the members of either Noctuidae and/or Pyralidae (Baker et al., 1995; Dweck et al., 2008). Bracon hebetor (Hymenoptera: Braconidae) appears to be used in IPM programs. The integrated uses of natural enemy's particularly $B$. hebeter to eradicate some pests with different selective pesticides appear possible to conserve the parasitoids (Vahid Mahdavi, 2013). This parasitoid can easily be mass reared and released in the open fields for control of many lepidopteran insects.

Integration between chemical pesticides and bio-control agents were used in Integrated Pest Management programs as mentioned by Zhao (2000) and Abedi (2012). Application of chemical control should be used only when it is necessary and when it can be least disruptive to biological control (Jepson, 1989; Rafiee-Dastjerdi et al., 2009).

Beside the abovementioned words, the integrated pest management systems attempt to apply both natural enemies and pesticides for pest control (Banks and Stark, 1998). Integrating the application of biocontrol agents and pesticides for pest management requires knowledge about the impact and selectivity of the pesticides, on natural enemies 
(Croft, 1990).

In this study, the author aims to test three pesticides, which were selected to investigate their lethal effects on $B$. hebetor, one of the most efficient parasitoid on the lepidopterous pests to examine their toxicity.

\section{Materials and Methods}

\subsubsection{Rearing the greater wax moth}

Adults of Galleria mellonella were collected and placed in plastic jars furnished with folded paper sheets for mating and eggs deposition. The eggs were incubated at $30 \pm 2{ }^{\circ} \mathrm{C}$ and $70 \pm 5 \% \mathrm{RH}$ until larval hatching. The larval stages were reared on an artificial diet according to Metwally (2013).

\subsubsection{Rearing of Bracon hebetor}

Adults of Bracon bebetor were obtained from National Research Centre maintaining culture. A newly emerged female and male were incubated in plastic gars for mating. Then mated female and male were isolated in separated cups, which supplied with drops of honey as food source. Last larval instar of G. mellonella as egg-deposition site of the parasitoid were introduced. The parasitized larvae were transferred to Petridishes and kept at incubator $\left(26 \pm 2^{\circ} \mathrm{C}, 60 \pm 5 \% \mathrm{RH}\right)$ until adult parasitoid emergence as described by Eylem (2005).

\subsubsection{Bioassay and technique of the treatment}

- IGR (Runner) (Methoxyfenazide, $240 \mathrm{SC}$ ). The recommended concentration is (150ml/200L water).

- Cyfluthrin: The recommended concentration is $(250 \mathrm{ml} / 200 \mathrm{~L})$.

- Profenofos 50 EC: The recommended concentration is $(750 \mathrm{ml} / 200 \mathrm{~L})$.

The 5 used concentrations/each tested material were prepared as follows:

\begin{tabular}{cccc}
\hline Concentration & Profenofos & Cyfluthrin & Runner \\
\hline $1^{\text {st }}$ & $150 \mu \mathrm{l} / 80 \mathrm{ml}$ & $50 \mu \mathrm{l} / 80 \mathrm{ml}$ & $30 \mu \mathrm{l} / 80 \mathrm{ml}$ \\
\hline $2^{\text {nd }}$ & $75 \mu \mathrm{l} / 80 \mathrm{ml}$ & $25 \mu \mathrm{l} / 80 \mathrm{ml}$ & $15 \mu \mathrm{l} / 80 \mathrm{ml}$ \\
\hline $3^{\text {rd }}$ & $37.5 \mu \mathrm{l} / 80 \mathrm{ml}$ & $12.5 \mu \mathrm{l} / 80 \mathrm{ml}$ & $7.5 \mu \mathrm{l} / 80 \mathrm{ml}$ \\
\hline $4^{\text {th }}$ & $18.75 \mu \mathrm{l} / 80 \mathrm{ml}$ & $6.25 \mu \mathrm{l} / 80 \mathrm{ml}$ & $3.75 \mu \mathrm{l} / 80 \mathrm{ml}$ \\
\hline $5^{\text {th }}$ & $9.37 \mu \mathrm{l} / 80 \mathrm{ml}$ & $3.12 \mu \mathrm{l} / 80 \mathrm{ml}$ & $1.88 \mu \mathrm{l} / 80 \mathrm{ml}$ \\
\hline
\end{tabular}

\subsection{Techniques applied}

Artificial diet $(20 \mathrm{~g})$ was mixed with $2 \mathrm{ml}$ of each tested concentration per each examined material. Ten of $5^{\text {th }}$ instar larvae of $G$. mellonella were feeding on each treated diet for three days. After three days, the percentage of mortality for each concentration was recorded. Each alive larva was transferred separately in a plastic cup with one pair of Bracon hebetor adults for 2 days. The number of deposited parasitoid's eggs on each larva, the percentage of hatchability, the larval duration, the pupal formation percentage and the adult emergence percentages were recorded. The check (control) group was feeding on untreated artificial diet and exposed to parasitoid adults too. 


\subsection{Statistical analysis}

Abbott's formula (Abbott, 1925), was applying to correct the percentage of mortality. Analysis of variances (ANOVA) F-test was carried out through the SPSS Computer program to discriminate between treatments and/or concentrations. Differences between means were compared using DMRT (Duncan, 1955). The LCvalues were calculated according to Finny (1971).

\section{Results}

\subsection{Direct Toxicity on B. hebtor}

Under laboratory constant conditions $\left(20 \pm 1^{\circ} \mathrm{C} \& 65 \% \mathrm{RH}\right)$, the mortality percentage of $B$. hebetor adults treated with Profenofos, Cyfluthrin and Runner (applying residual film technique) was recorded for the five concentrations previously mentioned for each of the three tested materials.

The $\mathrm{LC}_{50} \&$ the $\mathrm{LC}_{95}$ values were summarized in Table (1). It was noticed that, Cyfluthrin was more toxic and effective one of the tested pesticide, where the $\mathrm{LC}_{50}$ value was $3.640 \mu \mathrm{l} / 80 \mathrm{ml}$ water, followed by Runner (the $\mathrm{LC}_{50}$ was $10.874 \mu \mathrm{l} / 80 \mathrm{ml}$ water) then Profenofos (the $\mathrm{LC}_{50}$ was $69.445 \mu \mathrm{l} / 80 \mathrm{ml}$ water) (Table 1 ).

Table (1): The $\mathrm{LC}_{50} \& \mathrm{LC}_{95}$ values for each tested material

\begin{tabular}{cccc}
\hline Treatments & $\begin{array}{c}\mathrm{LC}_{50} \\
(\mu \mathrm{l} / 80 \mathrm{ml} \text { water })\end{array}$ & $\begin{array}{c}\mathrm{LC}_{95} \\
(\mu \mathrm{l} / 80 \mathrm{ml} \text { water })\end{array}$ & Slope $\pm \mathrm{SE}$ \\
\hline Runner & $10.874 \mu \mathrm{l}$ & $8958.338 \mu \mathrm{l}$ & $0.564 \pm 0.134$ \\
Cyfluthrin & $3.640 \mu \mathrm{l}$ & $109.790 \mu \mathrm{l}$ & $1.112 \pm 0.151$ \\
Profenofos & $69.445 \mu \mathrm{l}$ & $2848.033 \mu \mathrm{l}$ & $1.020 \pm 0.142$ \\
\hline
\end{tabular}

\subsection{Indirect Toxicity of on $\mathrm{B}$. hebrtor}

Toxic effects of five concentrations of the three tested materials (Profenofos, Cyfluthrin \& Runner) on the larval parasitoid, $B$. hebetor immature stages at all periods of parasitism vary significantly with that of the check (control)(Table 2).

\subsubsection{Effect of examined concentrations of Profenofos}

Data in table (2) showed that egg hatchability of the B. hebetor that parasitized on Galleria last larval instar which was feed on treated artificial diet at $1^{\text {st }}$ and $2^{\text {nd }}$ concentrations there was a significant different with that of the check $\left(F=2.798^{*}\right)$, but insignificantly differs was observed between the other three concentrations and the check.

On the other hand the percentage of pupation showed insignificant difference with each other but all showed a highly significant different with that of the check $\left(\mathrm{F}=5.011^{* *}\right)$. While the percentage of the adult parasitoid emergence at $1^{\text {st }}, 2^{\text {nd }}$ and $3^{\text {rd }}$ treatment showed significant difference if compared with the check. On the other hand, $4^{\text {th }} \& 5^{\text {th }}$ treatments showed insignificant difference with that of the check. Finally, insignificant difference was observed between the $1^{\text {st }}, 2^{\text {nd }}, 4^{\text {th }}$ and $5^{\text {th }}$ treatments between each other (Table 2). 


\subsubsection{Effect of examined concentrations of Cyfluthrin}

Generally, all concentrations of Cyfluthrin applied to the host of B.hebetor induced highly significant differences for the percentage of egg hatchability, percentage of pupation and percentage of adult emergence too, when compared with that of the check $\left(\mathrm{F}=8.002^{* *}, 13.226^{* *}\right.$ and $20.475^{* *}$, respectively)(Table 2$)$.

For the egg hatchability, it was observed that, the (5 $5^{\text {th }}$ concentration) was significantly different with either the $1^{\text {st }}$ or the $2^{\text {nd }}$ treatment, where insignificant differences were observed between $1^{\text {st }}, 2^{\text {nd }}, 3^{\text {rd }}$ or $4^{\text {th }}$ concentrations each other (Table 2 ). On the other hand, the percentage of pupation, nearly the same trend was observed where all the tested concentrations were significantly different with that of check. Larval parasitoid previously contaminated throughout their host, which was feed on Galleria larvae treated with the $4^{\text {th }}$ concentration showed higher significant difference than that treated with the $1^{\text {st }}, 2^{\text {nd }}$ or the $4^{\text {th }}$ concentration, also, it was observed that, the $1^{\text {st }}$ concentration induced complete failure in pupation and consequently, inhibit the adult formation and/or emergence.

On the other hand, either the $1^{\text {st }}$ and the $2^{\text {nd }}$ concentrations were prevent completely the formation of the adults; being significantly differ with the check and/or the $4^{\text {th }}$ treatment. Although there were different in the percentage of adult emergence at the $1{ }^{\text {st }}$, $2^{\text {nd }}, 3^{\text {td }}$ and $5^{\text {th }}$ concentrations, but they were statistically insignificantly differs; but were statistically different when compared with the check (Table 2).

\subsubsection{Effect of examined concentrations of Runner}

Generally, almost all concentrations of Runner applied to the host larvae of B.hebetor showed significant lower percentage of hatchability, percentage of pupation and the percentage of adult emergence, with respect to that of the check $\left(\mathrm{F}=2.630^{*}\right.$, $\mathrm{F}=7.126^{* *}$ and $7.626^{* *}$, respectively) (Table 2 ). On the other side, both the $4^{\text {th }}$ and the $5^{\text {th }}$ concentrations were insignificantly different with the check (untreated) in case of percentage of hatchability.

While as for pupation, there was a significant difference between $1^{\text {st }}$ and $3^{\text {rd }}$ treatments each other; on the other word, the $1^{\text {st }}, 2^{\text {nd }}, 4^{\text {th }}$ and $5^{\text {th }}$ concentrations showed insignificant differences between each other, but both were significantly different when compared with the check (Table 2). As for the adult emergence, there was insignificant difference between all treatments, but all of them were significantly differs with the check (Table 2).

\subsection{Comparison between three tested insecticides}

The obtained data shown in Table (3) point out that the percentages of hatchability, pupation or adult emergence at the $1^{\text {st }}$ concentration of the three tested materials (Profenofos, Cyfluthrin or Runner) were significantly lower than that of the check of each case, where the F-values were 11.236**, 12.718** and 17.645**, respectively. On the other hand, this reduction in pupation percentage in case of Cyfluthrin caused the failure of the parasitoid to form adult stage (Table 3).

The same trend was observed in case of the $2^{\text {nd }}$ concentration for all application, which showed highly significant reduction in the percentages of hatchability, pupation and adult emergence if compared with that of the control, but insignificant difference within each other. Also, Cyfluthrin application prevents completely the adult emergence. 
With respect to the $3^{\text {rd }}$ concentration the hatchability of the parasitoid that treated with Runner was significantly different from that of the control, but was insignificantly difference with either Profenofos or Cyfluthrin. Nearly, the same trend was observed for the percentages of pupation and adult emergence (Table 3).

As for the $4^{\text {th }}$ concentration treatment, it was noticed that, there was insignificant difference in the percentage of the parasitoid's hatchability in Profenofos and Runner treated host and those of the check, while the significant difference was observed between Cyfluthrin treatment and the check. In addition, insignificant difference was observed between the three tested insecticides (Profenofos, Cyfluthrin and Runner) each other (Table 3). On the other hand, the percentage of pupal formation from the pretreated host for the three tested materials was insignificantly differ between each other, but all were significantly differ with that of the check.

The percentage of adult emergence at this concentration had clear diversity, where there was insignificant difference between Profenofos and the check group, in one side, and Profenofos and Cyfluthrin on the other side. While Runner treatment exhibited a significant differences if compared with either the check group or with Profenofos treatment, but it was insignificantly different with those of Cyfluthrin treatment (Table 3).

At the $5^{\text {th }}$ concentration, the percentage of hatchability was insignificantly different between the three tested materials each other, also, all treatments were insignificantly differs with the check, except the Cyfluthrin treatment. In case of percentage of pupation, the check group and Profenofos treatment were significantly different with all other tested insecticides, on one side, while Cyfluthrin and Runner treatments were insignificantly differed with each other, but significantly different with the others. The percentage of adult emergence, there was insignificantly different between Profenofos and the check group, but both were significantly different with Cyfluthrin and Runner (Table 3).

\section{Discussion}

The use of the bio-control agents in pest management programs is badly needed. It is also necessary to take into concern, the adverse effects of commercial pesticides applied in fields on natural enemies. For this reason, our study evaluated the effects of some widely applied insecticides used for insect pest control and their impacts on the larval ecto-parasitoid Bracon hebetor.

The direct application of the tested insecticides induced drastic effect on the adult male and/or female parasitoid, leading to $100 \%$ mortality within $24-48$ hours post treatment for Cyfluthrin, 7 days post treatment for Runner treatment and 6 days post treatment for Profenofos.

Indirect toxicity of Cyfluthrin, Profenofos and Runner to the larval parasitoid, $B$. hebetor indicated that the larval and pupal periods were differed significantly with the control at all periods of parasitism, this result was in agreement with the results reported by Anne et al. (2001) who mentioned that longevity of parasitoids surviving a sub-lethal dose was reduced.

In our results, the different effects on parasitoid's adult because of pesticides treatments were obvious at different stages of development, that the parasitoid mortality was increased with time. These results are confirmed by that reported by Khan et al. 
(2005\&2009). They studied the different effects of pesticides on the parasitoid Bracon bebetor, where they reported that as time increased, mortality increased, and this may indicate a direct relationship between these two parameters. Our investigations showed that Profenofos at $1^{\text {st }}$ concentration are less toxic towards the B. bebetor than other applications. These results agreed with that obtained by Vahid Mahdavi (2013) who showed that spinosad and abamectin are less toxic than carbaryl and thiodicarb on B.hebetor. The results also confirm the results of Abedi (2012), who reported that biological pesticides had less of an impact on natural enemies. Also, Reddy et al. (1997) reported that insecticide treatments with 5 different at different concentrations, were ranked slightly harmful to harmful after 48 hours post treatment. The results were in agreement with that done by Faal-MohammadAli (2010) who reported that conventional pesticides such as chlorpyrifos were reported to be highly toxic to $H$. hebetor. Hooshmandi et al. (2012) was investigated the effects of new pesticides on $H$. hebetor and reported that the thiacloprid pesticide can be used successfully in pest control programs. These results of ours are consistent with the results of Baker et al. (1995). Also, the results reported by Reddy et al. (1997), clarify that monocrotophos and quinalphos were toxic to Bracon hebetor. Sarmadi (2008) showed that imidacloprid has a lower negative impact on the parasitoid $H$. bebetor. The results of our evaluation showed little contact toxicity for the imidacloprid pesticide, at different times.

According to the obtained results, Cyfluthrin used at various concentrations, had the most adverse effect on $H$. bebetor, and then Profenofos, then followed by Runner treatments which had lower toxicity than the other treatments. Results of our study clarify that, Cyfluthrin treatments were associated with the highest mortality percentage, which could be used as a chemical materials to control insect pests.

\section{Conclusion}

Cyfluthrin induced a higher toxic effects than Profenofos and/or Runner on the larval parasitoid, B.hebetor leading to the low number of emerged adults or may be completely inhibit the adult emergence. It could be concluded that the using of Profenofos for controlling many insect pests is safer enough for the larval parasitoid, $B$. bebetor than Cyfluthrin and Runner.

Table (2): Effect of tested insecticide on some biological aspects of Bracon hepetor (Mean \pm SE)

\begin{tabular}{cccc}
\hline \multirow{2}{*}{$\begin{array}{c}\text { Concentration } \\
(\mathrm{ml} / \mathrm{L})\end{array}$} & $\begin{array}{c}\text { Egg hatchability } \\
(\%)\end{array}$ & $\begin{array}{c}\text { Pupation } \\
(\%)\end{array}$ & Adult emergence $(\%)$ \\
\cline { 2 - 4 } & \multicolumn{3}{c}{ Profenofos } \\
\hline $1^{\text {st }}(150 \mu \mathrm{l} / 80 \mathrm{ml})$ & $37.25 \pm 14.59 \mathrm{~b}$ & $35.64 \pm 13.69 \mathrm{~b}$ & $42.60 \pm 15.37 \mathrm{bc}$ \\
$2^{\text {nd }}(75 \mu \mathrm{l} / 80 \mathrm{ml})$ & $36.36 \pm 15.56 \mathrm{~b}$ & $26.16 \pm 12.22 \mathrm{~b}$ & $46.29 \pm 17.61 \mathrm{bc}$ \\
$3^{\text {rd }}(37.5 \mu \mathrm{l} / 80 \mathrm{ml})$ & $64.17 \pm 16.22 \mathrm{ab}$ & $26.86 \pm 13.00 \mathrm{~b}$ & $32.69 \pm 14.23 \mathrm{c}$ \\
$4^{\text {th }}(18.75 \mu \mathrm{l} / 80 \mathrm{ml})$ & $63.36 \pm 16.71 \mathrm{ab}$ & $40.25 \pm 12.17 \mathrm{~b}$ & $63.75 \pm 14.88 \mathrm{abc}$ \\
$5^{\text {th }}(9.37 \mu \mathrm{l} / 80 \mathrm{ml})$ & $75.93 \pm 11.65 \mathrm{ab}$ & $57.62 \pm 11.43 \mathrm{~b}$ & $75.57 \pm 9.86 \mathrm{ab}$ \\
Control & $92.60 \pm 0.97 \mathrm{a}$ & $91.20 \pm 0.89 \mathrm{a}$ & $90.60 \pm 1.01 \mathrm{a}$ \\
F-value & $2.798^{*}$ & $5.011^{* *}$ & $3.043^{*}$ \\
Sig. & 0.027 & 0.001 & 0.018 \\
\hline
\end{tabular}




\begin{tabular}{cccc}
\hline \multicolumn{4}{c}{ Cyfluthrin } \\
\hline $1^{\text {st }}(50 \mu \mathrm{l} / 80 \mathrm{ml})$ & $8.89 \pm 8.89 \mathrm{c}$ & $0.00 \pm 0.00 \mathrm{c}$ & $0.00 \pm 0.00 \mathrm{c}$ \\
$2^{\text {nd }}(25 \mu \mathrm{l} / 80 \mathrm{ml})$ & $13.89 \pm 11.11 \mathrm{c}$ & $11.11 \pm 11.11 \mathrm{c}$ & $0.00 \pm 0.00 \mathrm{c}$ \\
$3^{\text {rd }}(12.5 \mu \mathrm{l} / 80 \mathrm{ml})$ & $28.55 \pm 14.55 \mathrm{bc}$ & $19.28 \pm 11.37 \mathrm{bc}$ & $15.69 \pm 10.13 \mathrm{bc}$ \\
$4^{\text {th }}(6.25 \mu \mathrm{l} / 80 \mathrm{ml})$ & $41.41 \pm 14.31 \mathrm{bc}$ & $42.36 \pm 14.85 \mathrm{~b}$ & $35.18 \pm 14.21 \mathrm{~b}$ \\
$5^{\text {th }}(3.12 \mu \mathrm{l} / 80 \mathrm{ml})$ & $55.38 \pm 16.49 \mathrm{~b}$ & $12.00 \pm 12.00 \mathrm{c}$ & $16.67 \pm 16.67 \mathrm{bc}$ \\
Control & $92.60 \pm 0.96 \mathrm{a}$ & $91.20 \pm 0.89 \mathrm{a}$ & $90.60 \pm 1.01 \mathrm{a}$ \\
F-value & $8.002^{* *}$ & $13.226^{* *}$ & $20.475^{* *}$ \\
Sig. & 0.000 & 0.000 & 0.000 \\
\hline \multicolumn{4}{c}{ Runner } \\
\hline $1^{\text {st }}(30 \mu \mathrm{l} / 80 \mathrm{ml})$ & $38.23 \pm 13.14 \mathrm{~b}$ & $46.87 \pm 17.95 \mathrm{~b}$ & $15.54 \pm 10.87 \mathrm{~b}$ \\
$2^{\text {nd }}(15 \mu \mathrm{l} / 80 \mathrm{ml})$ & $43.33 \pm 15.58 \mathrm{~b}$ & $25.47 \pm 13.58 \mathrm{bc}$ & $32.14 \pm 16.37 \mathrm{~b}$ \\
$3^{\text {rd }}(7.5 \mu \mathrm{l} / 80 \mathrm{ml})$ & $45.83 \pm 17.75 \mathrm{~b}$ & $7.81 \pm 7.81 \mathrm{c}$ & $10.12 \pm 10.11 \mathrm{~b}$ \\
$4^{\text {th }}(3.75 \mu \mathrm{l} / 80 \mathrm{ml})$ & $59.29 \pm 14.22 \mathrm{ab}$ & $33.52 \pm 11.59 \mathrm{bc}$ & $18.52 \pm 12.56 \mathrm{~b}$ \\
$5^{\text {th }}(1.88 \mu \mathrm{l} / 80 \mathrm{ml})$ & $61.00 \pm 10.34 \mathrm{ab}$ & $26.00 \pm 12.40 \mathrm{bc}$ & $20.00 \pm 20.00 \mathrm{~b}$ \\
Control & $92.60 \pm 0.97 \mathrm{a}$ & $91.60 \pm 0.89 \mathrm{a}$ & $90.60 \pm 1.01 \mathrm{a}$ \\
F-value & $2.630^{*}$ & $7.126^{* *}$ & $7.626^{* *}$ \\
Sig. & 0.037 & 0.000 & 0.000 \\
\hline
\end{tabular}

** Highly significant * Significant Values between bracts are the
concentration used. Means in a column followed with the same letter(s) are insignificantly different at $5 \%$ level of probability.

Table (3): Comparison between the three tested insecticides at each concentration

\begin{tabular}{|c|c|c|c|c|c|c|}
\hline & Meam \pm SE & & & & & \\
\hline $1^{\text {st }}$ concentration & $\begin{array}{l}\text { Profenofos } \\
(150 \mu \mathrm{l} / 80 \mathrm{ml})\end{array}$ & $\begin{array}{l}\text { Cyfluthrin } \\
(50 \mu \mathrm{\mu l} / 80 \mathrm{ml})\end{array}$ & $\begin{array}{l}\text { Runner } \\
(30 \mu \mathrm{l} / 80 \mathrm{ml})\end{array}$ & Control & F-value & $P$ \\
\hline$\%$ Hatchability & $37.25 \pm 14.59 \mathrm{~b}$ & $8.89 \pm 8.89 \mathrm{~b}$ & $38.23 \pm 13.14 \mathrm{~b}$ & $92.60 \pm 0.97 \mathrm{a}$ & $11.236^{* *}$ & 0.000 \\
\hline$\%$ Pupation & $35.64 \pm 13.69 \mathrm{~b}$ & $0.00 \pm 0.00 \mathrm{c}$ & $46.87 \pm 17.95 \mathrm{~b}$ & $91.20 \pm 0.89 \mathrm{a}$ & $12.718^{* *}$ & 0.000 \\
\hline$\%$ Adult emergence & $42.60 \pm 15.37 \mathrm{~b}$ & $0.00 \pm 0.00 \mathrm{c}$ & $15.54 \pm 10.87 \mathrm{bc}$ & $90.60 \pm 1.01 \mathrm{a}$ & $17.645^{* *}$ & 0.000 \\
\hline $2^{\text {nd }}$ concentration & $\begin{array}{l}\text { Profenofos } \\
(75 \mu \mathrm{l} / 80 \mathrm{ml})\end{array}$ & $\begin{array}{l}\text { Cyfluthrin } \\
(25 \mu \mathrm{l} / 80 \mathrm{ml})\end{array}$ & $\begin{array}{l}\text { Runner } \\
(15 \mu \mathrm{l} / 80 \mathrm{ml})\end{array}$ & Control & F-value & $P$ \\
\hline$\%$ Hatchability & $36.36 \pm 15.56 \mathrm{~b}$ & $13.89 \pm 11.11 \mathrm{~b}$ & $43.33 \pm 15.58 \mathrm{~b}$ & $92.60 \pm 0.97 \mathrm{a}$ & $9.044^{* *}$ & 0.000 \\
\hline$\%$ Pupation & $26.16 \pm 12.22 \mathrm{~b}$ & $11.11 \pm 11.11 \mathrm{~b}$ & $25.47 \pm 13.58 \mathrm{~b}$ & $91.20 \pm 0.89 \mathrm{a}$ & $13.801^{* *}$ & * 0.000 \\
\hline$\%$ Adult Emergence & $46.29 \pm 17.61 \mathrm{~b}$ & $0.00 \pm 0.00 \mathrm{c}$ & $32.14 \pm 16.37 \mathrm{~b}$ & $90.60 \pm 1.01 \mathrm{a}$ & $13.860 * *$ & $* 0.000$ \\
\hline $3^{\text {rd }}$ concentration & $\begin{array}{l}\text { Profenofos } \\
(37.5 \mu \mathrm{l} / 80 \mathrm{ml})\end{array}$ & $\begin{array}{l}\text { Cyfluthrin } \\
(12.5 \mu \mathrm{l} / 80 \mathrm{ml})\end{array}$ & $\begin{array}{l}\text { Runner } \\
(7.5 \mu \mathrm{l} / 80 \mathrm{ml})\end{array}$ & Control & F-value & $P$ \\
\hline \% Hatchability & $64.17 \pm 16.22 \mathrm{ab}$ & $28.55 \pm 14.55 \mathrm{~b}$ & $45.83 \pm 17.75 \mathrm{~b}$ & $92.60 \pm 0.96 \mathrm{a}$ & $4.375^{*}$ & 0.011 \\
\hline$\%$ Pupation & $26.86 \pm 13.00 \mathrm{~b}$ & $19.28 \pm 11.37 \mathrm{~b}$ & $7.81 \pm 7.81 \mathrm{~b}$ & $91.20 \pm 0.89 \mathrm{a}$ & $16.210^{* *}$ & ${ }^{*} 0.000$ \\
\hline$\%$ Adult Emergence & $32.69 \pm 14.23 \mathrm{~b}$ & $15.69 \pm 10.13 \mathrm{~b}$ & $10.12 \pm 10.12 \mathrm{~b}$ & $90.60 \pm 1.01 \mathrm{a}$ & $14.510^{* *}$ & $* 0.000$ \\
\hline $4^{\text {th }}$ concentration & $\begin{array}{l}\text { Profenofos } \\
(18.75 \mu \mathrm{l} / 80 \mathrm{ml})\end{array}$ & $\begin{array}{l}\text { Cyfluthrin } \\
(6.25 \mu \mathrm{l} / 80 \mathrm{ml})\end{array}$ & $\begin{array}{l}\text { Runner } \\
(3.75 \mu \mathrm{l} / 80 \mathrm{ml})\end{array}$ & Control & F-value & $P$ \\
\hline \% Hatchability & $63.36 \pm 16.71 \mathrm{ab}$ & $41.41 \pm 14.31 \mathrm{~b}$ & $59.29 \pm 14.22 \mathrm{ab}$ & $92.60 \pm 0.96 \mathrm{a}$ & $3.061 *$ & 0.043 \\
\hline$\%$ Pupation & $40.25 \pm 12.17 \mathrm{~b}$ & $42.36 \pm 14.85 \mathrm{~b}$ & $33.52 \pm 11.59 \mathrm{~b}$ & $91.20 \pm 0.89 \mathrm{a}$ & $6.869 * *$ & 0.001 \\
\hline$\%$ Adult Emergence & $63.75 \pm 14.88 \mathrm{ab}$ & $35.18 \pm 14.21 \mathrm{bc}$ & $18.52 \pm 12.56 \mathrm{c}$ & $90.60 \pm 1.01 \mathrm{a}$ & $8.317 * *$ & 0.000 \\
\hline $5^{\text {th }}$ concentration & $\begin{array}{l}\text { Profenofos } \\
(9.37 \mu \mathrm{l} / 80 \mathrm{ml})\end{array}$ & $\begin{array}{l}\text { Cyfluthrin } \\
(3.12 \mu \mathrm{l} / 80 \mathrm{ml})\end{array}$ & $\begin{array}{l}\text { Runner } \\
(1.88 \mu \mathrm{l} / 80 \mathrm{ml})\end{array}$ & Control & F-value & $P$ \\
\hline \% Hatchability & $75.93 \pm 11.65 \mathrm{ab}$ & $55.38 \pm 16.49 \mathrm{~b}$ & $61.00 \pm 10.34 \mathrm{ab}$ & $92.60 \pm 0.96 \mathrm{a}$ & $2.617 *$ & 0.072 \\
\hline$\%$ Pupation & $57.62 \pm 11.43 \mathrm{~b}$ & $12.00 \pm 12.00 \mathrm{c}$ & $26.00 \pm 12.40 \mathrm{c}$ & $91.20 \pm 0.89 \mathrm{a}$ & $12.956^{* *}$ & $* 0.000$ \\
\hline$\%$ Adult Emergence & $75.57 \pm 9.86 \mathrm{a}$ & $16.67 \pm 16.67 \mathrm{~b}$ & $20.00 \pm 20.00 \mathrm{~b}$ & $90.60 \pm 1.01 \mathrm{a}$ & $11.169^{* *}$ & $* 0.000$ \\
\hline
\end{tabular}




\section{Reference}

Abbott W.S. 1925. A method of computing the effectiveness of an insecticide. J. Econ. Entomol., 18: 265267.

Abedi Z. 2012. Lethal and sub-lethal effects of azadiactin, pyridalil, cypermethrin and methoxyfenozide on biological parameters of Habrobracon hebetor Say (Hym.: Braconidae). M.Sc. thesis, University of Maragheh, Iran, 104 pp.

Anne A, Anne MC, Jean PN, Jean PA. (2001) Selectivity assessment of chlorfenvinphos reevaluated by including physiological and behavioral effects on an important beneficial insect. Environmental Toxicologyand Chemistry.;20(11):2530-2536.

Baker J.E., Weaver D.K., Throne J.E., Zettler J.L. (1995). Resistance to protectant insecticides in two field strains of the stored-products insect parasitoid, Bracon bebetor (Hymenoptera: Braconidae). J. Econ. Entomol., 88 (3): 512-519.

Banks J.E., Stark J.D. 1998. What is Ecotoxicology? An Ad-Hoc Grab Bag or an Iterdisciplinary Science? Integrative Biol. 1 (5): 195-204.

Croft B.A. 1990. Arthropod Biological Control Agents and Pesticides. John Wiley and Sons, New York, 723 pp.

Duncan D.B. 1955. Multiple ranges and multiple F-test. Biometrics, 11: 1-42.

Dweck H.K.M., Gadallah N.S., Darwish E. (2008). Structure and sensory equipment of the ovipositor of Habrobracon hebetor (Say) (Hymenoptera: Braconidae). Micron 39 (8): 125-126.

Ebeid, A.R.; E.A. Sammour and Nawal Zohdy M. Zohdy (2015). Role of Challenger pesticide and plant extracts on some physiological parameters of the cotton leafworm, Spodoptera littoralis (Boisd.). Archives of Phytopathology and Plant Protection, 48(5): 385-392.

Endo S., Tsurumachi M. (2001). Insecticide susceptibility of the brown planthopper and the white-back planthopper collected from Southeast Asia. J. Pestic. Sci. 26 (1): 82-86.

Eylem Akman g.ND.Z, Adem G.LEL (2005). Investigation of Fecundity and Sex Ratio in the Parasitoid Bracon hebetor Say (Hymenoptera: Braconidae) in Relation to Parasitoid Age. Turk J Zool 29 . 291294.

Faal-MohammadAli H. 2010. The sub-lethal effects of chlorpyrifos and fenpropatrin on the biological parameters and functional response of Habrobracon hebetor Say (Hymenoptera:Braconidae) in the laboratory condition. M.Sc. Thesis, Shahid Chamran Ahvaz University, Khozestan, Iran, 128 pp.

Finny, D.J. (1971). Probit analysis. Cambridge: Cambridge University Press. 333 p.

Hooshmandi M., Alichi M., Minaei K., Aleosfoor M. 2012. Toxicity estimation of insect growth regulators insecticides (IGR); match, lufox and calypso on adult parasitoid wasp (Habrobracon hebetor) (Hym. Braconidae) under laboratory condition. In proceedings of the 20th Iranian Plant Protection congrees. University of Shiraz, Fars, Iran, 25-28 August, 381 pp.

Jepson P.C. 1989. The temporal and spatial dynamics of pesticide side-effects on non-target invertebrates. p. 95-128. In: "Pesticides and Non-Target Invertebrates" (P.C. Jepson, ed.). Wimborne: Intercept Ltd., 240 pp.

Khan R.R., Ashfaq M., Rana SH.A. 2005. Some studies on the toxicity of conventional and new chemistry insecticides against Bracon bebetor Say (Hym.: Braconidae) under laboratory conditions. Pak. Entomol. 27 (1): 19-21.

Khan, R.R., Ashfaq, M., Ahmed, S. and Sahi, S.T. 2009. Mortality responses in Bracon bebetor (Say) (Braconidae: Hymenoptera) against some new chemistry and conventional insecticides under laboratory conditions. Pak. J. Agri. Sci., 46(1): 30-35.

Metwally, H. M. (2013). Improving production and potency of bio-insecticides based on entomopathogenic nematodes. Ph.D. Thesis, Entomology Dept., Faculty of Science, Ain Shams Univ., Egypt, pp: 142.

Rafiee-Dastjerdi H., Hejazi M.J., Nouri-Ganbalani G.H., Saber M. 2009. Effects of Some Insecticides on Functional Response of Ectoparasitoid, Habrobracon hebetor (Say) (Hym.: Braconidae). J. Entomol. 6 (3): 161-166.

Reddy, G.R.S., Sreelatha and B.J. Divakar. 1997. Toxicity of six insecticides to two species of Bracon. Ind. J. Plant Prot. 25: 135-136. 
Sarmadi S. 2008. Laboratory investigation on lethal and sublethal effects of imidacloprid, indoxacarb and deltamethrin on parasitoid wasp Habrobracon hebetor Say (Hymenoptera: Braconidae). M.Sc. thesis, University of Mohaghegh Ardabili, Ardabil, Iran, 103 pp.

Tanaka K., Endo S., Kazano H. 2000. Toxicity of insecticides to predators or rice. planthoppers: spiders, the mirid bug and the dryinid wasp. Appl. Entomol. Zool. 35 (1): 177-187.

Vahid Mahdavi (2013): Residual toxicity of some pesticides on the larval ectoparasitoid, Habrobracon hebetor say (Hymenoptera: Braconidae). J. of plant protection research Vol. 53, No. 1.

Way M.J., Heong K.L. 1994. The role of biodiversity in the dynamics and management of insect pests of tropic irrigated rice: a view. Bull. Entomol. Res. 84: 567-587.

Zhao S.H. 2000. Plant Chemical Protection. China Agricultural Press, Beijing, China, 337 pp. 